\title{
Nigeria's Development Objectives in Time Perspective: Issues of Structural Constraints.
}

\author{
${ }^{1}$ Edame, Greg Ekpung, ${ }^{2}$ Anam, Bassey Ekpenyong ${ }^{3}$ Eneji Rapheal Oko \\ ${ }^{I}$ Department of Economics University of Calabar, Calabar-Nigeria. \\ ${ }^{2}$ Institute of Public Policy \& Administrarion, University of Calabar, Calabar-Nigeria. \\ ${ }^{3}$ Department of Special Education, University of Calabar, Calabar-Nigeria.
}

\begin{abstract}
Issues on economic development have been central in most developing economics of the world, which Nigeria is not exceptional. In the 1960s, the term "development" was equated with one form of economic development, which concentrated on industrial development and measured success only in terms of growth in Gross National Product (GNP) The choice is not between 'economic' and 'social' development. Economic development is central to qualitative changes in poor people's life. It is far more comprehensive. It includes not only economic growth but implies progressive changes in the socio-economic structures of a country which contributes to better living standard of their inhabitants The average growth rate of real GDP, which was 5.9 per cent in the period 1960-70, rose to 8.0 per cent in $1971-73$. The Nigerian economy expanded rapidly, as oil production and export rose phenomenally. Thus, annual GDP grew from a negative 0.6 per cent in 1987 to 13.0 per cent in 1990. However, the average growth rate of real GDP dropped to 1.9 per cent during 1991 1998. This was in spite of the favourable developments in the agricultural and services sub-sectors of the economy. Real GDP growth rate rebounded to 8.3 per cent during the period $1999-2007$, reflecting improved economic policy of NEEDS era. Despite the decline in real GDP growth rate to 6.3 per cent in the period 2008 -2009, the major drivers remained agriculture, wholesale and retail trade, and services sectors. Indeed, the last decade has been a period of rebirth as affirmed by almost all macroeconomic indicators. But the growth rate has not been high enough to push down the poverty profile.
\end{abstract}

Keywords: Agriculture, Export, Economic development, Industries, Macroeconomic, Gross National Product, Gross Domestic Product.

\section{Introduction}

Issues on economic development have been central in most developing economics of the world, which Nigeria is not exceptional. In the 1960s, the term "development" was equated with one form of economic development, which concentrated on industrial development and measured success only in terms of growth in Gross National Product (GNP) (Brookfield, 1975; Ickis; 1983). The problem with these narrow concepts of development became apparent quickly. In spite of growth in the GNP, there was increasing disparity between the rich and poor, and the lack of improvement in the standard of living of the masses in the growth in the GNP.

Thereafter, the term "Social Development" emerged as a concept that emphasizes the "human" dimension of development. Korten (1983) notes that the term social development has often been used simply as a way to express "concern for the human outcomes of development action", whereas it should be reserved for a more powerful ideas, "that people are the central purpose" of development and that human will and capacity are its most critical resource. This emerged the dichotomy between those whose focus is economic development and those concerned about human development. Gamanya et. al. (1986) argued that this is a false dichotomy. The choice is not between 'economic' and 'social' development. Economic development is central to qualitative changes in poor people's life. It is far more comprehensive. It includes not only economic growth but implies progressive changes in the socio-economic structures of a country which contributes to better living standard of their inhabitants (Kintu, 2008).

Sen (1957) acknowledge that 'development requires the removal of major sources of un-freedom, poverty as well as systematic social deprivation neglect of public facilities as well as intolerance or over activity of repressive states'. It is important pertinent to note that economic development is not possible without growth but growth is just increase in GDP (Kindleberges, 1965 and Myrdal, 1966). Economic development is significant in any economy as it leads to improvements in the socio-economic conditions of the people, especially in health, education, population control, housing etc. Therefore, a common question in the development economic debate is "why are poor countries poor?"

Evidence from most developing countries indicates that their underdeveloped economic characteristics further inhibit development strategies. These factors, among many others include vicious circle of poverty, unstable political condition, low rate of capital formation, untrained human resources, poor foreign exchange, 
socio-cultural barriers etc (Jhingan, 1966). According to the classical economist, capital formation is the most important factor of economic development but poverty in developing countries is the main cause of the shortage of capital, increasing population, shortage of electricity supply, corruption, government expenditure, technological advancement etc. are also factors that inhabit economic development of a country.

Nigerian economy has recorded rising growth in the Gross Domestic Product (GDP) especially over the past decades. But this has not translated to accelerated employment and a reduction in poverty among its citizens. This has caused the country to re-examine its development strategies. One of such was the enacted of the Millennium Development Goals (MDGs). Primarily, the goal is focused at improvement the socioeconomic status of the nation. Targeted for full actualization in 2015, available economic performance shows that the expectation which is left with four (4) for actualization may become unrealistic. While we argue on the possibilities of this expectation, it is important to note that there are certain structural constraints interfering with the strategy. This paper is set to examine certain structural constraints affecting the attainment of Nigeria's economic objectives.

Nature and Structure of the Nigerian Economic

Nigeria is the single largest geographical unit in West Africa. It occupies within the tropics with two areas of 923,768 square kilometers and lies entirely within the tropics with two main vegetation zones; the rain forest and Savannah zones, reflecting the amount of rainfall and its spatial distribution.

Structurally, the Nigerian economy can be classified into three major sectors namely, primary agriculture and natural resources; secondary - processing and manufacturing; and tertiary services sectors. The economy is characterized by structural dualism. The agricultural sector is an admixture of subsistence and modern farming, while the industrial sector comprises modern business enterprises which co-exist with a large number of micro-enterprises employing less than 10 persons mainly located in the informal sector. The agricultural sector has not been able to fulfill it traditional role of feeding the population, meeting the raw material needs of industries, and providing substantial surplus for export. Indeed, the contribution of the sector to total GDP has fallen over the decades, from a very dominant position of 55.8 per cent of the GDP in 1960 70 to 28.4 per cent in $1971-80$, before rising to 32.2 and 40.3 per cent during the decades $1981-90,1991-$ 2000 and $2001-2009$, respectively (Table 1). The fall is not because a strong industrial sector is displacing agriculture but largely as a result of low productivity, owing to the dominance of peasant farmers and their reliance on rudimentary farm equipment and low technology. Another feature of the sector is undercapitalization which results in low yield and declining output, among others.

Table 1: Classification of some sectors of the economy in Nigeria (1960-2009)

\begin{tabular}{|c|c|c|c|c|c|}
\hline Activity sector & $1960-1970$ & $\begin{array}{l}1971- \\
1980 \\
\end{array}$ & $\begin{array}{l}1981- \\
1990 \\
\end{array}$ & $\begin{array}{l}1991- \\
2000 \\
\end{array}$ & $\begin{array}{l}2001- \\
2009 \\
\end{array}$ \\
\hline 1. Agriculture & 55.8 & 28.4 & 32.3 & 34.2 & 40.3 \\
\hline 2. Industry & 11.3 & 29.1 & 41.0 & 38.6 & 28.4 \\
\hline 3. Manufacturing & 6.6 & 7.3 & 6.1 & 4.9 & 3.9 \\
\hline 4. Building \& Construction & 4.8 & 8.3 & 2.3 & 1.8 & 1.8 \\
\hline 5. Wholesale \& Retail Trade & 12.8 & 17.6 & 14.5 & 13.8 & 14.0 . \\
\hline 6. Services & 15.3 & 16.5 & 9.8 & 11.5 & 15.5 \\
\hline Total Value Added & 100.0 & 100.0 & 100.0 & 100.0 & 100.0 \\
\hline Diversification Index & 0.2 & 0.4 & 0.4 & 0.4 & 0.3 \\
\hline
\end{tabular}

Source: National Bureau of Statistics (2009)

The industrial sector comprises the manufacturing, mining (including crude petroleum and gas) and electricity generation. Prior to independence in 1960, the Nigerian economy was mainly agrarian. On attainment of independence, the Nigerian government embarked on the programme of transforming the country into an industrial economy. The Nigeria manufacturing sub-sector is made up of large, medium and small enterprises, as well as cottage and hand craft units. In spite of spirited efforts made to boost manufacturing output and various policy regimes, manufacturing has not made any significant contribution to the growth of the economy. Industry as a whole contributed only 11.3 per cent of the GDP in 1960-70, growing significantly in the next two decades to a height of 41.0 per cent in $1981-1990$, owing largely to the crude petroleum and gas production during the decades. The contribution contracted to 38.6 per cent in the 1990s and further to 29.4 per cent during $2001-2009$. These numbers, in fact, belie the poor contribution of the manufacturing sub-sector to aggregate output in Nigeria compared with its peers in Asia and Latin America. Indeed, the contribution of the manufacturing component has on average been below 5.0 per cent in the last two decades. Even the relatively high contribution of oil sector to the industrial sector contribution is being driven largely by crude production and not by the associated 'core industrial' components like refining and petrochemicals. The contribution of wholesale and retail trade and services has more or less remained stable while that of building and contribution rose sharply from 5.3 per cent in the 1960s to 8.3 per cent in the 1970s, but fell consistently, thereafter, to 1.8 per cent during 2011 - 2009. During and some few years after SAP, the main manufactured exports were 
textiles, beer and stout, cocoa butter, plastic products, processed timber, tyres, bottled water, soap and detergents as well as iron rods. However, some of these products have disappeared from the export list owing to poor enabling environment.. The components of the mining sub sector in Nigeria are crude petroleum, gas and solid minerals. Prior to the advent of petroleum minerals such as coal and tin were the main mineral exports. However, with the emergence of crude oil, the relative importance of solid minerals diminished. Indeed, since the 1970s, the largest mining activity has been crude oil production, which became dominant in terms of government revenue and export earnings. Lately the production of gas has gained increased attention, as the export potential of gas has reduced the dominance of crude oil.

Performance Trends

The average growth rate of real GDP, which was 5.9 per cent in the period 1960-70, rose to 8.0 per cent in 1971 - 73 (Table 2). The Nigerian economy expanded rapidly, as oil production and export rose phenomenally. However, activities in the service sub-sector were relatively modest even though marketing and advertising, which covers distributive trade, lagged behind. The average GDP growth rate later dropped to 3.2 per cent during 1976-80. This level was sustained in the period 1982-90 following improved performance in agricultural and industrial sub-sectors.

\begin{tabular}{l} 
Table 2: Average Growth Rate of Real GDP (Percentages) \\
\begin{tabular}{|l|l|}
\hline Period & Real GDP \\
& \\
\hline $1960-1970$ & 5.9 \\
$1971-1973$ & 8.0 \\
$1976-1980$ & 3.2 \\
$1982-1990$ & 3.2 \\
$1991-1998$ & 1.0 \\
$1999-2007$ & 8.3 \\
$2008-2009$ & 6.3 \\
& \\
\hline
\end{tabular} \\
\hline
\end{tabular}

Suffice it to state that GDP responded favorably to the economic adjustment policies of the eighties during which the SAP and economic liberalization were adopted. Thus, annual GDP grew from a negative 0.6 per cent in 1987 to 13.0 per cent in 1990 . However, the average growth rate of real GDP dropped to 1.9 per cent during 1991 - 1998. This was in spite of the favourable developments in the agricultural and services subsectors of the economy. Real GDP growth rate rebounded to 8.3 per cent during the period $1999-2007$, reflecting improved economic policy of NEEDS era. Despite the decline in real GDP growth rate to 6.3 per cent in the period 2008 - 2009, the major drivers remained agriculture, wholesale and retail trade, and services sectors. Indeed, the last decade has been a period of rebirth as affirmed by almost all macroeconomic indicators (Table 3). But the growth rate has not been high enough to push down the poverty profile.

\begin{tabular}{l} 
Table 3: \\
\begin{tabular}{|l|l|l|l|l|l|l|l|l|l|}
\hline Indicator & $\mathbf{2 0 0 3}$ & $\mathbf{2 0 0 4}$ & $\mathbf{2 0 0 5}$ & $\mathbf{2 0 0 6}$ & $\mathbf{2 0 0 7}$ & $\mathbf{2 0 0 8}$ & $\mathbf{2 0 0 9}$ & Average \\
\hline $\begin{array}{l}\text { Real GDP } \\
\text { growth rate }\end{array}$ & 9.57 & 6.58 & 6.51 & 6.0 & 6.5 & 6.4 & 6.7 & 6.2 \\
\hline $\begin{array}{l}\text { Inflation (y- } \\
\text { on-y) }\end{array}$ & 13.9 & 15.4 & 17.9 & 8.5 & 6.6 & 15.1 & 12.0 & 13.3 \\
\hline $\begin{array}{l}\text { Growth in } \\
\text { M2 }\end{array}$ & 24.97 & 12.26 & 34.61 & 30.6 & 44.2 & 58.0 & 17.1 & 13.8 \\
\hline $\begin{array}{l}\text { Current } \\
\text { account } \\
\text { balance/GDP }\end{array}$ & 6.95 & 17.62 & 28.23 & 18.5 & 11.8 & 17.5 & 11.9 & 13.4 \\
\hline $\begin{array}{l}\text { FDI (US S } \\
\text { billions) }\end{array}$ & 2.0 & 1.86 & 4.98 & 13.9 & 5.6 & 5.8 & & & \\
\hline $\begin{array}{l}\text { Exchange } \\
\text { rate (end- } \\
\text { period) }\end{array}$ & 129.4 & 133.5 & 132.15 & 128.2 & 117.9 & 132.5 & 149.58 & 125.8 \\
\hline $\begin{array}{l}\text { Extemal } \\
\text { debt (US S } \\
\text { billions) }\end{array}$ & 3.3 & 3.5 & 2.0 & 3.5 & 3.6 & 3.7 & 3.9 & 3.21 \\
\hline
\end{tabular} \\
\hline
\end{tabular}

Source: CBN Annual Report and Statement of Accounts Various Issues 
Indeed, the Nigerian economy has not experienced remarkable transformation and restructuring. Equally important is the indication that since 1999, Nigeria has become a trading outpost for goods produced elsewhere with little domestic transformation of the output of primary sectors by the secondary sector. This is particularly so since the Nigerian agriculture is really peasantry and the high contributions of tertiary sector to output suggest that the sector is not really servicing the Nigerian economy but, indeed, the economies of her trading partners. Thus, the Nigerian economy is still dominated by the primary sector, followed rather closely by the tertiary sector with the contribution of the secondary sector remaining insignificant. Little wonder the diversification index remained below 0.4 per cent through the review period, the barrage of reforms notwithstanding.

The Nigerian economy is import dependent with very little non-oil exports. It relies heavily on crude oil and gas exports with other sectors trailing far behind. For example, crude oil accounts for about 90 per cent of foreign exchange earned by the country while non-oil exports account for the balance. The economy is, therefore, susceptible to shocks in the oil industry. In recent times, these shocks have been caused by either developments in the International crude oil market or the restiveness in the Niger Delta region of the country. Agriculture and other mining (besides oil and gas) have been abandoned to the rural poor. Economic and social infrastructure, especially power is grossly dilapidated. The power sector is generally recognized as a binding constraint on Nigeria economy. Poor corporate governance, both in the public and private sectors have led to high incidence of corruption and inequity in income distribution.

Table 4: Composition of Nigerian Exports
\begin{tabular}{|l|l|l|l|l|l|l|}
\hline Component & $\mathbf{2 0 0 4}$ & $\mathbf{2 0 0 5}$ & $\mathbf{2 0 0 6}$ & $\mathbf{2 0 0 7}$ & $\mathbf{2 0 0 8}$ & $\mathbf{2 0 0 9}$ \\
\hline Oil Exports & 97.5 & 98.3 & 97.8 & 97.9 & 99.0 & 95.8 \\
\hline $\begin{array}{l}\text { Total Non oil } \\
\text { Export }\end{array}$ & 2.5 & 1.7 & 2.2 & 2.1 & 1.0 & 4.2 \\
\hline Non oil & & & & & & \\
\hline Agric & 33.0 & 41.9 & 37.8 & 39.7 & 58.3 & 46.9 \\
\hline Minerals & 2.0 & 4.0 & 8.5 & 6.3 & 7.7 & 6.7 \\
\hline $\begin{array}{l}\text { Semi- } \\
\text { Manufactured }\end{array}$ & 48.9 & 40.6 & 37.9 & 39.4 & 17.0 & 29.2 \\
\hline Manufactured & 5.0 & 9.8 & 11.1 & 10.3 & 8.7 & 9.1 \\
\hline $\begin{array}{l}\text { Other } \\
\text { Exports }\end{array}$ & 11.2 & 3.9 & 4.7 & 4.3 & 8.3 & 8.1 \\
\hline
\end{tabular}
\begin{tabular}{l} 
Source: CBN Annual Report and Statement of Accounts \\
\hline
\end{tabular}

A review of the statistics from comparable countries shows that the share of primary commodities in total exports is 20.0 percent for Malaysia, 24.0 per cent for India, 12.0 per cent for China. For developed countries it is 17 per cent for Britain and America and 9 per cent for Japan. In Nigeria, the primary sector contributes 99 per cent of exports with only 1.0 per cent coming from the secondary sector.

Table 5: Composition of Exports in Selected Developed and Developing Countries 2007
\begin{tabular}{|l|l|l|l|}
\hline Countries & $\begin{array}{l}\text { Export as a \% of } \\
\text { GDP }\end{array}$ & $\begin{array}{l}\% \text { share of primary } \\
\text { commodities }\end{array}$ & $\begin{array}{l}\% \text { of manufactured } \\
\text { goods }\end{array}$ \\
\hline Developing Countries & & & 80 \\
\hline Malaysia & 110.0 & 20 & 54 \\
\hline Indonesia & 40.7 & 46 & 70 \\
\hline Jamaica & 19.6 & 30 & 41 \\
\hline Philippines & 53.2 & 59 & 91 \\
\hline Bangladesh & 11.9 & 9 & 1 \\
\hline Nigeria & 48.7 & 99 & 12 \\
\hline Venezuela & 27.2 & 88 & 75 \\
\hline Sri Lanka & 33.0 & 25 & 23 \\
\hline Kenya & 15.9 & 77 & 91 \\
\hline South Korea & 37.8 & 9 & 18 \\
\hline Togo & 25.0 & 82 & 85 \\
\hline Mexico & 29.0 & 15 & 76 \\
\hline India & 8.3 & 24 & 54 \\
\hline Brazil & 9.4 & 46 & 88 \\
\hline China (excl. Hong Kong) & 23.1 & 12 & \\
\hline Developed Countries & & & 83 \\
\hline United Kingdom & 19.8 & 17 & 83 \\
\hline United States & 7.9 & 17 & 94 \\
\hline Japan & 10.2 & 6 & \\
\hline So & & \\
\hline
\end{tabular}

Source: World Bank, 2007 World Development indicators

Before the discovery of growth oil, agriculture has been the major growth driver in Nigeria. Agriculture dominated the primary sector, which dominated the entire economy. The population of the country has grown by about 150.0 per cent between 1963 and 2006, approximately 3.75 per cent per annum. A simple calculation 
shows that for the per capita income to remain the same as in the 1960s, every sector of the economy should at least have grown by the same percentage. But the agricultural sector - the mainstay of the economy - has declined in its contribution to the GDP, manufacturing has declined, building and construction has also declined, while the wholesale and retail trade as well as the services sectors have remained almost the same as in the 1960s.

Applying the Harrod-Domar model, this implies that assuming a capital-output ratio of 5.0 per cent and a saving ratio of 15.0 per cent, the economy would grow at 3.0 per cent. Of course, the savings ratio depends on the difference between the population growth rate and the growth rate of the GDP (the economy). Table 2 shows an average growth rate of real GDP of 5.3 per cent in the period $1960-2009$. If the average population growth rate of 3.8 is deducted from 5.3, we are left with a GDP growth rate of 1.5 per cent out of which no meaningful savings can be made. In effect, the economy has not been growing in real terms over the years. For Nigeria to make a quantum leap, the economy has to grow by at least double digit rates for a sustained period of time.

Structural Constraints to Economic Development in Nigeria

Nigeria is a mono-product economy with the bulk of government revenue coming from oil exports which is susceptible to shocks in the international oil market. Moreover, many other solid minerals with which the country is richly endowed with remain generally untapped. More fundamentally, the economy has disproportionately relied on the primary sector (subsistence agriculture and the extractive industry) without any meaningful value addition. In light of this, the little growth recorded in the economy, thus far, has been without commensurate employment, positive attitudinal change, value reorientation, and equitable income distribution, among others. These could be attributed to poor leadership, poor implementation of economic policies, weak institutions, poor corporate governance, endemic corruption, etc. The challenge, therefore, is how to deploy/manage the receipts from the oil and gas exports to achieve the highest value for money in the economy; develop on a sustainable basis, the many untapped solid minerals; improve agricultural productivity by cultivating more o the available arable land with improved technology; process and preserve primary produce with the aim of increasing value addition; manufacture the basic durable and non-durable goods needed by Nigerians and the West African sub-region, market and ultimately looking at export such goods and sustain manufacturing by providing the core industries; and remain competitive by developing and improving on the investment climate of the country. These challenges have remained largely unresolved owing to the myriad of problems:

\section{Macroeconomic Challenges:}

The Nigerian macro-economy is still characterized by structural rigidities, dualism and the false paradigm model. Generally, the sectors of the economy are in silos to the extent that the primary sector does not relate meaningfully with the secondary sector and the same for the secondary and the tertiary sectors. Agricultural produce end up as final consumer goods as only a small quantity is processed or used as raw materials for local manufacturing industries. Also, the products of the extractive industries are exported in their raw forms without local value addition. Given the higher incomes in the oil and gas sub-sector of the extractive industry, attention is concentrated there to the almost total neglect of the mainstream economy. Consequently, the economy is broken into the very rich (relying on the oil and gas industry) and the very poor (relying on the mainstream economy) with almost a complete vacuum in-between these two. The false paradigm model also plays out in the economy in the sense that while the few very wealthy group clamor for relevance in the context of 'expert' advise, the very poor suffer from ignorance, disease and malnutrition. Thus, there is no structural change and, hence, the attitudinal changes expected of economic transformation are absent.

\section{Under-investment in Human Capital Development:}

Human capital development required investment in education. Education is a merit good and the longterm benefit to the society is often considerably under perceived and therefore under -consumed.

For many in developing economics, the return on human capital development is uncertain compared to the immediate return from employment on the land. Educational quality has fallen over the last 20 years and new recruits typically need considerable amount of training for their jobs. But data on returns to education in Nigeria are low; private return to primary and secondary education is estimates between 2-4 percent per year; and return on post-secondary education is estimated at 10-15 percent. These estimates are low compared to the results for Latin America and Asia as estimated over 20 years ago. The fact that the structure of Nigerian industry is skewed towards low technology activities suggests that low human capital is still an important constraint to economic development (World Bank report, 2007). 


\section{Low Saving and Investment Constraint:}

Both saving and investment in Nigeria have historically been low relative to more rapid growing economies, investment has average 19.5\% of GDP while savings average about 18\% of GDP between 1980 and 2008. Although savings in Nigeria has been lower than investment it does not confirm with the classical growth theory.

Low return on investment appears to be the root of low investment and low growth in Nigeria. The low investment and growth in Nigeria appears to be low underlying returns driven in large part by the weak access to and poor quality of infrastructure. The high risk environment also limits the ability of firms to appropriate returns that may exist. The immediate focus of the government's growth strategy should therefore be on reform and investment that will improve investment returns, particularly enhancing the access to and quality of physical infrastructure. The next priority for policy marker's attention is instituting reforms that will raise the ability of economic agents to appropriate return. This refers to actions that will address macroeconomic instability, and microeconomic risk from corruption and related weaknesses.

\section{Volatile Economic Environment Constraint}

Nigerian's highly volatile economic environment makes it a risky environment for businesses and consequently increases the "transactions" cost of doing business. This reduces the ability of firms to appropriate returns. At the micro level risks raises from the corruption and related weaknesses of institutions that should facilitate private sector access to key business services (tax, trade facilitation, registration etc). Corruption and weak institutions have increase the cost of doing business for Nigerian firms through "unofficial payments" for access to basic business services, including public services, government contract etc. Nigerian public institution equality, integrity and efficiency is ranked poorly by private sector (World Bank Report, 2007).

\section{Population and Human Resources Constraint}

Population is a considerable constraint on economic development, most commonly, because there is a high rate of population growth for the country's current resources, or because the population is growing too slow or declining as a result of war famine or disease. Many economists see population growth as the single biggest issue facing developing economies (WTO Doha Development Round, 2007).

Underdeveloped human resources is an important obstacle to economic development in less develop countries such countries lack in people possessing critical skills and knowledge required for all round development of the economy. Under-developed human resources are manifest in low labour productivity, factors of immobility, limited specialization in occupation. Nigerian larger population of over 150 million is an important asset. However, its development lags behind that of several comparators (World Bank Report, 2007).

\section{Infrastructural Constraint:}

Infrastructure is central to economic development and economic competitiveness (Africa Global Competitiveness Initiative 2007). Much of Nigeria's public sector infrastructure dates from the 1970s and 1980s. Since then, under-investment in the rehabilitation and maintenance of the existing infrastructure, significance understanding on infrastructure, and the poor quality of this limited spending by government have resulted in the poor access and low quality of the available infrastructure. Nigeria ranks poorly on several indicators of infrastructure, access, cost and quality (World Bank Report, 2007).

Infrastructural constraint is experience in the following sectors: energy, transport and Information and Communication Technology (ICT). In power, the install generation capacity is $6,000 \mathrm{mw}$ compared to available energy output of only about 3,000 MW. Actual demand is estimated to be $10,000 \mathrm{MW}$. The transmission network is poorly configured for reliability and lines extend over distance that is too long for efficient and reliable load flows. Nigeria's port services are among the most inefficient and expensive in the world as evidenced by high waiting times, low handling speed and high container "dwell" times. Nigeria's railways services hardly function. The Infrastructure is dilapidated and there is a lack of serviceable locomotives and rolling stock.

\section{Rising hopes for the future}

The challenge is clear, the future is uncertain until proper measures are taken to tackle basic structural issues which affect the development process. Over the years, and now, policy measures across several sectors of the economy have been adopted to address the challenges of economic development and sustainability. While we hope for the actualization of the MGDs by 2015 and the Vision 20:20:20, continual efforts must be targeted at addressing basic structural issues. More efforts must be put into:

i. Diversifying the economy from its present mono state of overdependence on crude oil. Investment must be done to revive industries and promote commercial agriculture. 
ii. Increase in budgetary allocation for education, in other to achieve the goal of effective human capital development.

iii. Build and strengthen institutional capacities for optimum performance, reduce corruption and further strength national security.

iv. Create an enabling friendly economic environment that guarantees investment (especially small scale investment). Doing this will require steady power supply and reduction in excess taxes.

v. Provide basic economic needs for the vulnerable in rural areas; access to education, potable water, primary health, etc. doing this will guarantee improved productivity in the agricultural sector, which is mostly handled by this rural class.

\section{References}

[1]. Brookfield, H. (1975) Interdependence Development. Methuen: Longman.

[2]. Gamanya, W. E. Edgler, D. D., And Fried, S. W. (1986) Trade, Growth And Poverty. Economic Journal, Royal Economic Society Vol. 114(493) Pp. $22-49$.

[3]. Ickis J. C. (1983) Structural Responses To New Rural Development Strategies, In Bureaucracy And The Poor, Ed By D. C. Korten And F. B. Alfonso, Kumaria Press, West Hartford, Connecticut.

[4]. Kindleberger, C. F. (1965) Economic Development. 2nd Ed. New York: Mcgraw Hill Book Coy.

[5]. Kintu, A. O (2008). The Political Economy Of The Rent-Seeking Society, In: America Economic Review, Vol. 64 No. 3 Pp. 291 3030 .

[6]. Korten D. C. (1983) Social Development: Putting People First, In Bureaucracy And Alfonso. West Haartford: Kumarian Press

[7]. World Bank (2007) African Development Indicators, The International Bank For Reconstruction And Development/World Bank, Washington D.C. Usa. 